\title{
The defiant and the compliant: How does procedural justice theory explain ethnic minority group postures toward police?
}

Elise Sargeant ${ }^{\mathrm{ab} *}$, Nicholas Davoren ${ }^{\mathrm{a}}$ and Kristina Murphy ${ }^{\mathrm{ab}}$

${ }^{a}$ School of Criminology and Criminal Justice, Griffith University, Queensland, Australia;

${ }^{b}$ Griffith Criminology Institute, Griffith University, Brisbane, Australia;

*Corresponding Author: Dr Elise Sargeant, School of Criminology and Criminal Justice, Griffith University, Mount Gravatt, 176 Messines Ridge Road, Queensland, 4122 Australia,e.sargeant@griffith.edu.au

Funding: ARC Discovery Grant DP1093960; ARC Centre of Excellence Grant RO700002; ARC Discovery Grant DP1094589; ARC Discovery Grant DP170101149. 


\title{
The defiant and the compliant: How does procedural justice theory explain ethnic minority group postures toward police?
}

\author{
Understanding public dispositions to defy police is important for police practice. \\ Citizen defiance can result in arrest, injury or even death. The current study \\ examines the antecedents of "defiant" and "compliant" motivational postures \\ among a sample of 1,480 ethnic minority group members. Developing a better \\ understanding of defiant and compliant postures is important when studying \\ ethnic minority groups who may be more likely to defy police compared to \\ majority populations. Three competing theoretical models incorporating social \\ identity and procedural justice are tested: the group value, group engagement and \\ uncertainty management models. Each model variously seeks to explain how and \\ why procedural justice may foster or reduce compliant or defiant postures toward \\ police among ethnic minority group members. Upon testing these models we find \\ that the efficacy of procedural justice varies depending on which posture is \\ predicted.
}

Keywords: motivational postures; compliance; defiance; procedural justice; police; ethnicity

\section{Introduction}

"Much of policing consists of getting people to do things they might not otherwise do" (Mastrofski, Snipes and Supina, 1996, p. 269). To achieve this, police need public cooperation and compliance (Mastrofski et al., 1996). Preferably, police will be able to yield voluntary cooperation and compliance from the public. If compliance cannot be achieved voluntarily, the alternative is for police to use force, which can result in arrest, injury and, in extreme cases, death (Bozeman et al., 2018; MacDonald, Kaminsky and Smith, 2009).

In stable, democratic countries such as Australia, the UK, and the US, positive, compliant attitudes and behaviours toward police are the norm amongst the majority of the population (Braithwaite, 2009). However we know that some people are less likely 
to hold positive attitudes toward police than others. For example, research finds that some ethnic minority ${ }^{1}$ group members are less trusting of the police (e.g. Murphy and Cherney, 2012; Jackson, Bradford, Stanko and Hohl, 2013; Lai and Zhao, 2010; Sivasubramaniam and Goodman-Delahunty, 2008), less confident in police (e.g. Cao, Frank and Cullen, 1996), less willing to cooperate with the police (e.g. Griffiths, 2017; Sargeant, Murphy and Cherney, 2014; Viki, Culmer, Eller and Abrams, 2006), less satisfied with the police (e.g. Reisig and Parks, 2000), and more likely to hold defiant attitudes toward the police (e.g. Murphy and Cherney, 2012; Weitzer and Brunson, 2009).

In this paper we seek to better understand the disposition to comply with or defy the police among ethnic minority group members by examining the relationship between procedural justice, social identity and motivational postures. Motivational postures are one way of operationalising the disposition to comply with or defy the police, and can be defined as the amount of social distance an individual places between themselves and an authority (Braithwaite, 2003, 2009). Braithwaite's (2009) social distancing framework proposes that an individual will adopt particular psychological positions, or "postures", toward authority. These "motivational postures" represent the social distance that an individual places between themselves and an authority and capture whether or not an individual is willing to deal with an authority in a civil manner (Bogardus, 1928; Braithwaite, 2009). Compliant postures include: "commitment" and "capitulation", and defiant postures include "resistance", “disengagement" and "game-playing" (Braithwaite, 2009).

\footnotetext{
1 "Ethnicity" and "ethnic minority group" are the prefereed terms in the Australian context (in contrast to, for example, "race" or "people of colour").
} 
To predict the disposition to comply with or defy the police we examine the relationship between procedural justice, social identity and motivational postures. To do so we compare and contrast three theoretical models: the group value (GVM), group engagement (GEM) and uncertainty management (UMM) models. Each model employs social identity theory to draw a link between procedural justice, social identity and attitudes toward group authorities (Tyler and Blader 2003; Smith, Tyler, Huo, Oritz and Lind, 1998). Social identity frameworks are useful when investigating attitudes toward police among ethnic minority group members. This is because social identity can help to explain attitudes toward authorities among ethnic minority group members (Murphy and Cherney, 2012; Murphy, Sargeant and Cherney, 2015). Social identity frameworks may also help us to better understand the social distance placed between an individual and an authority (as in Braithwaites framework), as social distance may be guided by group identification (Murphy et al., 2009).

In order to compare and contrast the utility of the GVM, GEM and UMM in explaining motivational postures, we employ data collected from a sample of 1,480 ethnic minority group members living in Brisbane and Melbourne, Australia. Australia is a multicultural nation with numerous ethnic minority groups. The ethnic minority group members included in this study are: Indian ${ }^{2}$, Vietnamese and Arabic-speaking groups. These specific groups are selected for participation in this study because 1) they were, and are currently, prominent ethnic minority groups in Australia, comprising over three percent of the overall Australian population at the time of the survey (ABS, 2006); and 2) these populations have a history of problematic relationships with the police in

\footnotetext{
${ }^{2}$ I.e. people who identify as having Indian ancestry (associated with the country India).
} 
Australia (e.g. Dixon and Maher, 2002; Mason 2012; Meredyth, McKernan and Evans 2010; White 2009). ${ }^{3}$

The paper begins with an outline Braithwaite's (2009) social distancing framework. We then overview the three social identity theories and consider how these theoretical perspectives can explain the relationship between procedural justice and motivational postures for ethnic minority group members. We follow this discussion with our methods and results. We conclude with a discussion of the implications of our findings.

\section{Motivational Postures}

Braithwaite's $(2003,2009)$ social distancing theory provides a framework through which to view compliant and defiant attitudes toward authorities. Motivational postures reflect the amount of social distance an individual places between themselves and an authority (Braithwaite, 2003, 2009). Here, social distance represents the degree to which an individual is willing to associate with an authority on amiable terms and the degree to which an individual ascribes status to that authority (Bogardus, 1928; Braithwaite, 2009). Braithwaite $(2003,2009)$ identifies five motivational postures that reflect different levels of social distance. "Resistance", "disengagement" and "game-playing" are defiant postures that manifest as adverse attitudes and behaviours toward authorities. In contrast "commitment" and "capitulation" are compliant postures that characterise more positive attitudes and behaviours.

\footnotetext{
${ }^{3}$ A more in-depth discussion of this issue is provided in the Methods section below.
} 
Each of the five postures represent a different 'take' on defiance or compliance. Committers signal that they knowingly and willingly embrace the mission and purpose of authorities, and are willing to cooperate with the demands of authorities (Braithwaite, 2009). Capitulators are willing to cooperate with authorities but are motivated by the desire to keep authorities on-side, rather than sharing their mission and purpose (Braithwaite, 2009). Resisters object to the actions of authorities however they do not object to the power authorities hold (Braithwaite, 2009). Disengagers are dismissive of authorities, objecting to the power authorities hold, and, if authorities are not exercising their power visibly then disengagers consider authorities irrelevant (Braithwaite, 2009). Game-players are like disengagers in that they dismiss authorities' power, however, they also defiantly compete with authorities if the mission of these authorities conflicts with their own goals (Braithwaite, 2009). For example, in the taxation context, an individual "using the system" and exploiting loopholes in the law to achieve personal gains is characterised as "game-playing" (Braithwaite, 2009).

Braithwaite's $(2003,2009)$ social distancing framework advances traditional measures of the willingness to cooperate or comply with authority by encapsulating both the willingness to cooperate or comply with an authority as well as the manner in which an individual accepts or, importantly, rejects an authority. These dispositions to comply (or defy) are in turn found to predict cooperation and compliance across a range of regulatory contexts including taxation (Braithwaite, 2003; Hartner et al., 2008; Murphy 2016; Murphy, Tyler and Curtis, 2009); traffic violations (Factor et al., 2013); and social security contexts (Murphy et al., 2009).

Most relevant to the current research, a number of studies have examined the relationships between motivational postures and the willingness to cooperate with police and comply with the law (Murphy and Cherney, 2012; Murphy, 2016; Murphy et 
al., 2009). For example, Murphy et al. (2009) utilised data collected in both taxation and policing contexts to examine the relationship between procedural justice, law legitimacy, motivational postures and compliance and cooperation. Drawing on data collected from a sample of 652 Australian taxpayers, they found commitment predicted self-reported taxation compliance, and mediated the relationship between procedural justice/law legitimacy (an interaction term), and compliance. In a separate sample of 2,120 Australian citizens, Murphy et al. (2009) found commitment did not mediate the relationship between procedural justice, law legitimacy and the willingness to cooperate with police, however they concluded that high levels of commitment in their sample lead to a ceiling effect. Moreover they argued that as procedural justice was found to be positively related to compliant postures (commitment and capitulation), and negatively related to defiant postures (resistance and disengagement), procedural justice could be used "to shape the social distance people place between themselves and authority", and therefore to shape motivational postures toward authorities (Murphy et al., 2009, p. 18).

In a follow up study, Murphy (2016) examined the longitudinal relationship between procedural justice, motivational postures and compliance in both the taxation and policing contexts. In each context Murphy (2016) found that those who were resistant or disengaged were also less likely to comply (with the tax authorities) or cooperate (with police). Murphy (2016) also found that procedural justice was an important predictor of lower resistance over time (although procedural justice did not have the same predictive effect for disengagement). Together these findings further demonstrate how motivational postures can predict the willingness to cooperate and comply with authorities such as the police, and suggest the formation of these postures may be influenced by procedural justice. 
Research by Murphy and Cherney (2012) suggests that motivational postures may help to better understand ethnic minority group attitudes and behaviours toward police. Drawing on a sample of 1,203 Australians, Murphy and Cherney (2012) examined the relationship between procedural justice, law legitimacy and the willingness to cooperate with police, controlling for ethnic minority group status. Murphy and Cherney (2012) identified a three-way interaction effect between procedural justice, law legitimacy and ethnic minority-group status, when predicting the willingness to cooperate with police. Upon splitting the sample, they found that for ethnic minority group members who reported reduced perceptions of law legitimacy, procedural justice actually had a negative impact on their willingness to cooperate with the police. To explore these findings further Murphy and Cherney (2012) examined levels of disengagement (i.e. one motivational posture) among both samples. They found that the ethnic minority group members were more disengaged from the police compared to non-minority group members. Moreover, they found that disengagement mediated the effect of procedural justice on the willingness to cooperate with the police for ethnic minority group members. These results emphasise the need to better understand how motivational postures are formed among ethnic minority group members, and the role of procedural justice in their formation.

\section{Theoretical Frameworks}

In order to better understand the role of procedural justice in promoting (or mitigating) motivational postures among ethnic minority group members, the current study employs the GVM, GEM and the UMM. These models variously explain how social identity moderates or mediates the relationship between procedural justice and cooperation or compliance, with a particular focus on group membership (De Cremer and Sedikides, 2005; Tyler and Blader, 2003; Tyler, Degoey and Smith, 1996). Here social identity is 
defined as "the individual's knowledge that he[sic] belongs to certain social groups together with some emotional and value significance to him[sic] of this group membership" (Tajfel, 1972, p. 292). Each of the three theoretical models provides distinct hypotheses about how procedural justice and social identity will work together to explain attitudes to authorities among both majority and minority group members.

\section{The Group Value Model}

The GVM explains that the ability of a group authority to elicit compliant attitudes and behaviours among group members is contingent upon the importance individuals place on their status within the group that the authority represents (Tyler, 2006; Tyler and Lind 1992). The GVM proposes that procedural justice influences group members' attitudes by providing information relevant to their social identity (Tyler et al., 1996). Fair treatment and fair decision-making by authorities (procedural justice), communicates that the individual holds a positive, respected position within the group, while unfair treatment indicates marginality and disrespect (Tyler, 2006; Tyler and Lind 1992). Authorities' use of fair procedures also lead individuals to take pride in their group membership (Deutsch and Steil, 1988; Smith et al., 1998). Subsequently, the individual is more inclined to engage in prosocial behaviours, such as compliance with group authorities (Tyler et al., 1996). The GVM therefore asserts that procedural justice should matter more to those who identify more strongly with the group the authority represents. In the context of policing ethnic minority groups, the group the police represent is broader society (often defined as national identity). Thus, procedural justice should matter more for predicting attitudes toward police among ethnic minority group members who identify more strongly with the national identity. 


\section{The Group Engagement Model}

The GEM proposes that people use procedural justice judgements to determine whether or not group membership is likely to lead to a positive and satisfying self-identity; that is, whether or not they should invest their social identity into membership of a particular group (Tyler and Blader, 2000, 2003). The GEM emphasises that those who identify more strongly with a group will be more inclined to act in a way that promotes the common welfare of that group, including cooperating with that group's authorities (Blader and Tyler 2009; Tyler and Blader 2003). Like the GVM, the GEM proposes that authorities' behaviour contains information relevant to an individual's sense of self, and that this information will influence the individual's attitude towards that authority (Blader and Tyler 2009; Bradford, Murphy and Jackson, 2014; Tyler and Blader 2003). The key difference between the two models is that while the GVM predicts that an individual's social identity should moderate the relationship between procedural justice and attitudes and behaviour toward authorities, the GEM suggests that social identity should mediate this relationship - that is, procedural justice will foster or encourage social identity with the group the authority represents, which in turn leads to cooperation with group authorities (Tyler and Blader, 2003). In the context of ethnic minority groups attitudes, national identity should mediate the relationship between procedural justice and attitudes and behaviour toward the police.

\section{The Uncertainty Management Model}

The UMM is the third model to highlight the importance of social identity processes to understanding the relationship between procedural justice and the disposition to comply with or defy an authority. The model proposes that uncertainty about one's environment, or status within a societal group, leads to unpleasant cognitive and affective states (De Cremer and Sedikides, 2005; Wolfe et al. 2016). According to this 
model, procedural justice matters to people because it helps reduce the uncertainty they feel regarding their status within a group (De Cremer and Sedekides, 2005; De Cremer, Brebels and Sedekides, 2008). When an individual is uncertain about their status within a group, they are more likely to be influenced by the behaviour of that group's authorities, because they are seeking to define their role and alleviate the unpleasantness associated with such uncertainty (De Cremer and Sedekides, 2005). The relationship between procedural justice and identity proposed by the UMM, like the GVM is therefore one of moderation. Contrary to the GVM however, the UMM predicts that procedural justice should matter more to those who identify less strongly with the group the authority represents (indicative of uncertainty). The UMM would therefore suggest that procedural justice might be more effective in promoting dispositions to cooperate and comply with authorities (such as the police) for those who are marginalised from mainstream society - such as ethnic minority groups.

\section{The Current Study}

The three social identity theories (GVM, GEM, UMM) provide three plausible roadmaps for the relationship between procedural justice and motivational postures among ethnic minority group members. While these are not necessarily competing perspectives (they are better described as theoretical developments) testing the efficacy of each of these theoretical models will help to shed light on the conditions under which the groups are likely to reduce or increase the level of social distance they place between themselves and authorities. Braithwaite's (2009) social distancing framework proposes that the social distance an individual places between themselves and an authority predicts whether or not the individual is willing to deal with the authority in a civil manner or on friendly terms (Bogardus, 1928; Braithwaite, 2009). Thus 
understanding the predicates of motivational postures can help us to better understand the disposition to cooperate or comply with police.

Social identity theories are particularly useful in studies of ethnic minority groups because social identity theories draw on group membership to understand attitudes and behaviours toward authorities (e.g. Tajfel, 1972). In policing research, police are considered to be representative of a superordinate national identity, and an individual's level of identification with this superordinate group has important implications for the relationship between that individual and the police (e.g. Bradford 2014, Oliveira and Murphy, 2015; Murphy et al., 2015). In prior studies of policing, social identity and ethnic minority group membership, levels of national identity and ethnic minority group identity are found to impact upon attitudes and behaviours toward the police (e.g. Murphy and Cherney, 2011; Murphy et al., 2015).

The GVM, GEM and UMM each offer a different path to understanding the relationship between procedural justice, social identity and the disposition to comply with or defy the police. The present study draws on a sample of 1,480 Australian ethnic minority group members to test the utility of these three social identity models in explaining motivational postures toward police among ethnic minority group members. Each theoretical model puts forward distinct hypotheses about the relationship between procedural justice, social identity, and motivational postures. We outline these hypotheses below:

- Hypothesis 1: If the GVM is supported we anticipate superordinate identity will moderate the relationship between procedural justice and motivational postures, such that the relationship between procedural justice and motivational postures will be stronger for those with a higher superordinate identity. 
- Hypotheses 2 and 3: If the GEM is supported we expect procedural justice will lead to higher superordinate identity (Hypothesis 2), and that superordinate identity will mediate the relationship between procedural justice and motivational postures (Hypothesis 3).

- Hypothesis 4: If the UMM is supported we anticipate that superordinate identity will moderate the relationship between procedural justice and motivational postures such that this relationship will be stronger for those with a lower superordinate identity (indicative of uncertainty).

\section{Data and Sampling}

To test these hypotheses, the current study draws on data from the Ethnic Community Survey (ECS). The ECS is a survey of ethnic minority group members in Brisbane and Melbourne, Australia (Murphy et al., 2012), and is part of a larger study of community processes - the Australian Community Capacity Study (ACCS).

The ACCS involved a stratified sample. First, 298 suburbs were randomly drawn from the Brisbane Statistical Division and Major Statistical Region of Melbourne (see Mazerolle et al., 2012). Second, participants were randomly drawn from within these suburbs.

The ECS similarly drew participants from these 298 suburbs but, rather than from the general population, the focus was on selecting participants from three ethnic minority groups: Vietnamese, Indian, and Arabic-speaking groups. While Australia is a 
multi-cultural nation, without one clear minority group ${ }^{4}$, these groups were purposively selected because 1) they were, and are currently, prominent ethnic minority groups in Australia, comprising over three percent of the overall Australian population at the time of the survey (ABS, 2006); and 2) these populations have a history of problematic relationships with the police in Australia (e.g. Dixon and Maher, 2002; Mason 2012; Meredyth, McKernan and Evans 2010; White 2009). For example Arabic-speaking people in Australia have experienced heightened police attention following 9/11 and related terrorism threats to Australia (e.g. Poynting and Nobel, 2004; Poynting et al., 2004). Indian people in Australia have experienced spates of high profile incidents of racist victimisation that may have lead to distrust of the police (Dunn, Pelleri and Maeder-Han, 2011). Recent research also indicates that Vietnamese people in Australia distrust the police (Meredyth, McKernan, and Evans, 2010). ${ }^{5}$

The sample was selected using the common surnames method (Challice and Johnson, 2005) that utilises lists of frequent surnames for each ethnic minority group (e.g., Nguyen, Singh, Mohammad) as the sampling pool. Random digit dialling within this pool allowed for initial contact with participants. Face-to-face interviews were arranged with a willing participant who was over 18 years of age, and was next in the household to celebrate their birthday. Interviews were conducted over two phases: during September-December 2010 (Phase 1), and June-August 2011 (Phase 2). The overall cooperation rate (completed interviews/(completed interviews+refusals)) across

\footnotetext{
${ }^{4}$ For example, the Australian census collects data on over 30 ancentral groups living in Australia (ABS, 2013).

${ }^{5}$ For further discussion of the selection of these groups for the ECS, and experiences of these groups with police in Australia, see Murphy, Cramer, Waymire and Barkworth, 2018.
} 
both phases was $41.53 \%$ (44.04\% Phase $1 ; 39.02 \%$ Phase 2$)$. The sample used in the current study consisted of all valid responses from Phases 1 and 2. Face-to-face interviews (using a standardised questionnaire) were conducted by Cultural Partners, an organisation specialising in research with culturally and linguistically diverse communities. The participant chose the location of the interview and the language in which it was conducted. Participants were given a \$50AUD gift card for their participation.

\section{Sample Characteristics}

The final sample $(\mathrm{N}=1,480)$ was aged between 18 and 86 , with a mean age of 39.17 $(\mathrm{SD}=12.86)$. The slight majority of participants were male $(50.1 \%)$ and 50.9 percent were full-time employed. Overall, the sample was 32.9 percent Indian, 34.2 percent Vietnamese, and 32.9 percent Arabic-speaking.

\section{Measures}

Four motivational postures comprise the key dependent variables of interest in this study: commitment, capitulation, resistance and disengagement. Measures of motivational postures are based on those developed by Murphy, Murphy and Mearns (2010), drawing on Braithwaite's $(2003,2009)$ social distancing framework. Gameplaying was not measured in the ECS as it was perceived as less relevant to the policing context.

Commitment is defined as the belief that the police are legitimate and that citizens should defer to police authority because it is the right thing to do (Cherney and Murphy, 2011). Commitment is measured with three items, e.g. "Obeying the police is the right thing to do" $(\alpha=.760)$. Capitulation is defined as deferring to police authority out of fear and capitulating to police demands so as to avoid attention. Capitulation is 
measured using three items, e.g. "No matter how fair or unfair the police are, the best option is to always cooperate with them" $(\alpha=.649)$. Resistance is defined as acceptance of the police as a legitimate institution of social control, accompanied by an opposition towards the way they use their power (Cherney and Murphy, 2011). Resistance is measured with three items, e.g. "Police are more interested in catching you doing the wrong thing than helping you to the right thing" $(\alpha=.643)$. Disengagement is defined as the complete rejection of the police and their system of rules, reflective of a desire to step outside the system (Cherney and Murphy, 2011). Disengagement is measured with two items, e.g. "I do not care if I am not doing the right thing by police" $(\alpha=.634)$. All posturing items were measured on Likert scales ranging from $1=$ Strongly Disagree to 5=Strongly Agree.

Procedural Justice is defined as the perceived fairness of decision-making and treatment by police (e.g. Sunshine and Tyler, 2003). We measured procedural justice with seven items including for example: "Police try to be fair when making decisions" and "Police treat people fairly" $(\alpha=.887)$. Items were based on those employed in prior research (Murphy and Cherney, 2012; Murphy, Hinds and Fleming, 2008; Sunshine and Tyler, 2003; Tyler and Fagan, 2008). Procedural justice items were measured on Likert scales ranging from $1=$ Strongly Disagree to $5=$ Strongly Agree

Items measuring superordinate identity are based on a body of socialpsychological research examining identity and attitudes towards authorities (Huo et al., 1996; Huo, 2003; Tyler, Boeckmann, Smith and Huo, 1997). Superordinate identity is defined as the extent to which individuals identify with the superordinate group in society that the police represent (e.g. Bradford, 2014). In this study, superordinate identity reflects the extent to which the participant identified as Australian. It was measured with four items, e.g. "I see myself first and mainly as a member of the 
Australian community" $(\alpha=.769)$. Superordinate identity items were measured on Likert scales ranging from $1=$ Strongly Disagree to $5=$ Strongly Agree .

Demographic variables including age, gender, ethnicity, education, income and employment were included to control for the influence of respondent characteristics. Age was included as a continuous variable representing age in years. Gender was measured as a dichotomous variable (male $=1)$. Ethnicity was entered as a categorical variable with categories for Indian, Arabic Speaking, and Vietnamese (reference category) participants. Education was coded as a dichotomous variable, comparing those who had a trade, technical certificate, diploma, university/college degree, or postgraduate qualification (tertiary=1), and those who had completed only senior high school, junior high school, primary school, or had no schooling (other=0). Income was operationalised as the annual income of the individual's household. To measure income a dummy-variable was created to compare low and high income (\$39,990 AUD or less $=1 ; \$ 40,000$ AUD or more $=0$ ). Employment was operationalised as the individual's employment status at the time of the interview (full-time employed $=1$; other $=0$ ).

Considering the analysis is focused on attitudes toward police, it was important to control for prior police contact. Police contact was operationalised as a personal interaction with a police officer, excluding for work or social purposes, in the twelve months prior to the interview taking place. Police contact compared those who had had contact with the police one or more times (prior contact $=1$ ), to those who had had no contact with the police (no contact $=0$ ), in the last 12 months.

Finally, because the data was collected at two different time periods we controlled for survey phase. A dichotomous variable was conputed to represent survey phase (Phase $1=0$, Phase $2=1$ ). Descriptive statistics of the variables used in the 
analyses including percentage distributions for dichotomous variables are listed in Table 1 below.

[Insert Table 1 here]

\section{Results}

\section{Factor Analysis}

To determine the discriminant validity of our key variables we ran a factor analysis with varimax rotation. The factor analysis identified six unique factors representing commitment, capitulation, resistance, disengagement, procedural justice and social identity which guided the construction of measurement scales (as above). Continuous independent variables were mean centered. An interaction term was computed for procedural justice and social identity (procedural justice*social identity).

[Insert Table 2 here]

\section{Regression Analysis}

Ordinary least square regression analyses were estimated predicting each of the four motivational postures: commitment, capitulation, resistance and disengagement. For each analysis, variables were entered in blocks: demographic variables and police contact were added in Model 1, procedural justice in Model 2, superordinate identity in Model 3 and the interaction term in Model 4. Adding variables in blocks allowed us to test the mediation and moderation hypotheses. For each analysis we also tested for multivariate outliers. For the analyses predicting capitulation we removed 7 outliers that were having a significant influence on the results. We report the results predicting each dependent variable below. 


\section{Commitment}

Results predicting commitment are reported in Table 3. Of the variables entered in Model 1 only age and ethnicity are significantly associated with commitment. We find older participants are more committed to the police compared to younger participants $(\beta=.083 ; p \leq .001)$. These results are consistent with prior research that finds older people typically hold more positive atittudes toward the police (e.g. Brown and Benedict, $2002)^{6}$. We also find that Indian $(\beta=.151 ; p \leq .001)$ and Arabic-speaking $(\beta=.172$; $\mathrm{p} \leq .001)$ participants are more likely to be committed to the police, compared to Vietnamese participants. These results indicate that the disposition to commit varies across ethnic groups.

When entered in Models 2 and 3 respectively, procedural justice $(\beta=.387$; $\mathrm{p} \leq .001)$ and superordinate identity $(\beta=.190 ; \mathrm{p} \leq .001)$ are positively and significantly associated with commitment. These results show participants who perceive the police to be more procedurally just and who strongly identify with Australian society are more likely to be committed to the police. We also find support for a partial mediation effect: when superordinate identity is entered in Model 3, the strength of the relationship between procedural justice and commitment decreases. To confirm this partial mediation effect we ran an auxiliary model predicting superordinate identity finding procedural justice is positively and significantly associated with superordinate identity $(\beta=.173 ; \mathrm{p} \leq .001)$. A Sobel test confirmed that superordinate identity partially mediates

\footnotetext{
${ }^{6}$ While only $12 \%$ of our sample might be considered "young" (i.e. under the age of 25 ), the median age in our sample (39) is similar to that of the Australian population (37) at the time of the survey.
} 
the relationship between procedural justice and commitment $(z=5.345 ; \mathrm{p} \leq .001){ }^{7}$ These $^{2}$ results support Hypothesis 2 and provide partial support for Hypothesis 3. The addition of the interaction term $(\beta=-0.047 ; p>.05)$ in Model 4 is non-significant, suggesting that superordinate identity does not moderate the effect of procedural justice on commitment (i.e. Hypotheses 1 and 4 are not supported).

[Insert Table 3 here]

\section{Capitulation}

Results for our analysis predicting capitulation are reported in Table 4. In Model 1, age $(\beta=.082 ; p \leq .001)$ is significantly associated with capitulation. As with commitment, these results suggest that older participants are more likely to capitulate to police compared to younger participants. We also find that those with a tertiary education are less likely to capitulate $(\beta=-.062 ; \mathrm{p} \leq .05)$. This may be because tertiary educated participants are more likely to have a knowledge of the law and are subsequently more discerning when it comes to authorities and the law. Those with an Arabic-speaking $(\beta=.167 ; p \leq .001)$ ethnic background are more likely to capitulate to the police, compared to Vietnamese participants.

As with commitment, we find procedural justice $(\beta=.436 ; p \leq .001)$ (Model 2$)$ and superordinate identity $(\beta=.125 ; \mathrm{p} \leq .001)$ (Model 3$)$ are positively and significantly associated with capitulation. These results suggest that participants who believe police are procedurally just and who more strongly identify as Australian are more likely to

\footnotetext{
${ }^{7}$ Sobel tests were also calculated using Bootstrapped standard errors (1000 repetitions). There was no substantive difference in the significance of the coefficients and therefore these analyses have not been included in the final manuscript.
} 
capitulate to police. When superordinate identity is entered into Model 3 the strength of the relationship between procedural justice and capitulation decreases suggesting a partial mediation effect. To test for this we ran an auxiliary model (results as above) and conducted a Sobel test. The auxiliary model and the Sobel test $(z=4.050 ; \mathrm{p} \leq .001)$ show that superordinate identity partially mediates the relationship between procedural justice and capitulation, supporting Hypotheses 2 and $3^{8}$. The addition of the interaction term $(\beta=-0.007 ; p>.05)$ in Model 4 is non-significant indicating Hypotheses 1 and 4 are not supported.

Taken together the results for commitment and capitulation suggest that the GEM (i.e. social identity mediates the relationship between procedural justice and compliance) has the strongest explanatory power when predicting compliant motivational postures. However, it is important to note that superordinate identity does not play a stronger role in predicting the disposition to comply than procedural justice. The effect of procedural justice when predicting the disposition to comply appears to occur primarily independent of superordinate identity, at least in our sample of ethnic minority group members.

[Insert Table 4 here]

\section{Resistance}

Results for our analysis predicting resistance are reported in Table 5. In Model 1 we find that males are more likely to resistant police compared to females $(\beta=.063 ; p \leq .05)$

\footnotetext{
${ }^{8}$ Sobel tests were also calculated using Bootstrapped standard errors (1000 repetitions). There was no substantive difference in the significance of the coefficients and therefore these analyses have not been included in the final manuscript.
} 
and that those who have had prior contact with police in the 12 months $(\beta=.095$; $\mathrm{p} \leq .001)$ are more likely to be resistant. These results support prior research that finds males are less likely to hold posititive attitudes toward the police (e.g. Brown and Benedict, 2002), and that contact with police can leave a negative impression (Skogan, 2006). We also find Arabic-speaking $(\beta=.213 ; p \leq .001)$ and Indian $(\beta=.151 ; p \leq .001)$ participants are significantly more likely to be resistant toward the police, when compared to Vietnamese participants. Interestingly, these results somewhat contradict those found for the compliant postures where we found Vietnamese participants are less likely to hold a compliant disposition. This may indicate a tendency for the Vietnamese participants to hunker down and simply avoid interactions with police where possible.

In Model 2, procedural justice has the strongest relationship with resistance of the variables in the model $(\beta=-.236 ; p \leq .001)$. Unsurprisingly, this suggests that those who have poor perceptions of procedural justice are more likely to resist the police. Results in Models 3 and 4 are arguably more interesting. Here we find that even though superordinate identity is not a statistically significant predictor of resistance, the interaction term is $(\beta=-.095 ; \mathrm{p} \leq .001)$. To explore this relationship further the interaction term is plotted in Figure 1 (below). The plot shows that procedural justice matters more for predicting lower levels of resistance, when superordinate identity is higher. To confirm these results, simple slopes analyses are computed in STATA. Results of the simple slopes analysis are statistically significant for each slope, and are presented in Table 7. These results support Hypothesis 1.

[Insert Table 5 here]

[Insert Figure 1 here]

\section{Disengagement}


Results for our analysis predicting disengagement are reported in Table 6. In Model 1 only age $(\beta=-.058 ; p \leq .05)$ and Indian ethnic background $(\beta=.086 ; p \leq .01)$ are significant predictors of disengagement. These results suggest that older participants are less likely to be disengaged compared to younger participants and that Indian respondents are more likely to be disengaged compared to Vietnamese respondents. This second results is somewhat suprising considering that Vietnamese respodents are both more likely to comply with police and also more likely to resist police.

In Models 2 and 3 procedural justice $(\beta=-.012 ; p \geq .05)$ and superordinate identity $(\beta=.040 ; p \geq .05)$ are entered into the models and neither are statistically significant. The interaction term on the other hand is positive and significant $(\beta=.096 ; \mathrm{p} \leq .01)$ when entered into Model 4. To explore this relationship further the interaction term is plotted in Figure 2, and simple slopes analyses are computed. Analyses find that only the slope for low superordinate identity is significantly different from zero. As such the results of the interaction term suggest that higher levels of procedural justice predict lower levels of disengagement for those with a weak superordinate identity but procedural justice has no effect on disengagement levels for those with a higher level of superordinate identity. These results provide support for Hypothesis 4.

[Insert Table 6 here]

[Insert Figure 2 here]

\section{Discussion}

\section{Key Findings and Limitations}

In this paper we examined the relationship between procedural justice, social identity, and dispositions to comply with (or defy) the police, among ethnic minority group members in Australia.We operationalised the disposition to comply with or defy the 
police using Braithwaite's (2009) social distancing framework. To examine the way in which procedural justice and social identity may inform the development of motivational postures, we tested the utility of three theoretical models commonly used to explain attitudes and behaviour toward authorities: the GVM, GEM and UMM. We found various levels of support for each of these three theoretical models when predicting four of Braithwaite's (2009) motivation postures (commitment, capitulation, disengagement and resistence).

Before discussing our findings, it is important to acknowledge three key limitations of this research. First, the sample consists of individuals from three ethnic minority groups in Australia (those of Indian, Vietnamese, and Arabic-speaking backgrounds). The generalisability of these findings are therefore limited to these groups. Second, we note that as these participants were contacted by land-line telephone, it may be that we missed the opportunity to access individuals who no longer utilise a landline (although we note in our results that the average age of the sample seems to representative of the Australian population). Third, the data utilised in the study is cross-sectional. As such, a causal relationship between the variables of interest cannot be tested (but can be inferred). Third, the UMM focuses upon status-uncertainty. We operationalise this as low superordinate identity - however future research should incorporate a more specific measure of status-uncertainty.

Despite these limitations, our findings shed light on the utility of three socialidentity perspectives (the GVM, GEM and UMM) in explaining ethnic minority group motivational postures toward police. We found partial support for the GEM when predicting compliant postures, and support for the GVM and UMM when predicting resistance and disengagement (defiant postures) respectively. More specifically, we found that procedural justice and social identity are important predictors of compliant 
postures and that social identity partially mediates the relationship between procedural justice and compliance. These results provide partial support for the GEM. We found that procedural justice was most effective at reducing resistance (a defiant posture) when superordinate identity was higher, supporting the GVM. In contrast, we found that procedural justice was more effective at reducing disengagement (a defiant posture) when superordinate identity was lower, supporting the UMM. Taken together, these results suggest that, at least in the case of the ethnic minority groups under investigation, compliance and defiance do not appear to operate on a continuum. Instead, the impact of procedural justice and superordinate identity vary depending on whether we predict defiant or compliant motivational postures.

To unpack these results further let us revisit the key characteristics of these motivational postures starting with the compliant postures. Committers and capitulators are compliant and willing to cooperate with the demands of authorities (Braithwaite, 2009). The key difference between the two is that capitulators are motivated by the desire to keep authorities on-side, whereas committers also share the mission and purpose of said authorities (Braithwaite, 2009). The similar results across the two compliant postures suggest that procedural justice is important in communicating to ethnic minority group members that police are on their side, regardless of whether or not police communicate a shared mission and purpose. We conclude that procedural justice appears to have a direct effect on reducing the social distance that may exist between ethnic minority group members and police, encouraging a disposition to comply. This occurs regardless of whether or not procedural justice fosters a sense of social identity.

In contrast to committers and capitulators, resisters and disengagers are defiant. Resisters specifically differ from the compliant in that they object to the actions of 
authorities (but do not object to the power they hold) (Braithwaite, 2009). We found that procedural justice was effective at reducing resistance and particularly so when superordinate identity was higher, supporting the GVM. As the GVM explains, the ability of group authorities to elicit compliant attitudes and behaviours is contingent upon the importance individuals place on their status within the group. Our results suggest that ethnic minority group members who identify with the superordinate group (i.e. national identity) may be more receptive to hearing the message that police can act in a procedurally-fair way, and are therefore less likely to resist the police. In this way, social identity (in tandem with procedural justice) appears to be a key mechanism to reducing resistance toward police.

Like resisters, disengagers are also defiant and dismissive of authorities, objecting to the power authorities hold (Braithwaite, 2009). Moreover, if authorities are not exercising their power visibly, disengagers will consider these authorities irrelevant (Braithwaite, 2009). Our results predicting disengagement are perhaps the most interesting of the results reported here. Upon first glance, our results indicate that neither procedural justice nor social identity predict disengagement. However with the addition of the interaction term, we find that procedural justice appears to be effective at reducing disengagement when superordinate identity is lower, providing support for the UMM. These results suggest that for those ethnic minority group members who are uncertain about their status in society (as indicated by lower levels of superordinate identity), procedural justice can be used by police to reduce disengagement. As ClayWarner (2001, p. 224) argues "individuals tend to ignore procedural injustice when detection would damage their self-esteem in regard to group identity". Here we find this effect in reverse. It seems that those people who are seeking out identity relevant information are more likely to be impacted by procedural justice. Thus, while those who 
are disengaged may appear indifferent to police, it seems that - at least for those who have not developed a strong superordinate identity - procedural justice can be a convincing mechanism that may encourage ethnic minority group members to engage with police.

\section{Theoretical Implications}

Our results speak to two key questions about procedural justice highlighted in recent literature on the topic: 1) can procedural justice influence motivational posturing?; and 2) is the efficacy of procedural justice invariant? Prior research finds that motivational postures go a long way to explaining the willingness to cooperate and comply with authorities, by accounting for the degree of social distance an individual places between themselves and that authority (e.g. Braithwaite, 2003; Factor et al., 2013; Hartner et al., 2008; Murphy 2016; Murphy et al., 2009). Murphy et al. (2009, p. 18) suggest

procedural justice could be used "to shape the social distance people place between themselves and authority". Our findings generally support this conclusion (with the exception of the disengagement motivational posture) for ethnic minority groups.

As for the second question, currently, there is some debate as to whether procedural justice can promote cooperation and compliance similarly across all situations and contexts. While some research suggests that the effect of procedural justice on attitudes and behaviour towards authority is largely invariant (e.g. Wolfe et al., 2016), other research contends that social identity and ethnicity have the potential to influence the likely outcomes of procedural justice (e.g. Cherney and Murphy, 2011; Huo, 2003; Murphy, et al., 2015; Sargeant et al., 2014; Tankebe, 2009). Our findings suggest the impact of police use of procedural justice on attitudes toward compliance and defiance varies depending on the extent to which the individual identifies with the society that the police represent (i.e. superordinate identity). 
Our divergent findings across the compliant and defiant motivational postures add further fuel to the invariance thesis debate. We find that even within our sample of ethnic minority group participants, the efficacy of procedural justice (and the moderation/mediation effect of social identity) in promoting compliance and reducing defiance varies, depending on how dispositions to comply or defy the police are conceptualised and operationalised. Notably, we find a strong relationship between procedural justice and compliant postures that does not hold when predicting defiant postures (disengagement in particular). These results suggest the manner through which defiance is reduced is not directly inverse to the manner through which compliance is increased.

So what might explain these seemingly contradictory findings? The answer may lie in the way people interpret police behaviour. In his classic study, Skogan (2006, p. 99) describes the way people experience policing asymetrically: "At its worst, the police may get essentially no credit for delivering professional service, while bad experiences can deeply influence peoples' views of their performance and even legitimacy". In the case of our study, it may simply be that "good behaviour" (i.e. procedural justice) on the part of the police may be less useful at reducing "bad" attitudes (i.e. defiance) than engendering positive atittudes toward the police (i.e. compliance).

Despite suggestions or assumptions that compliance and defiance lie at opposite ends of a continuum (e.g. Braithwaite 2001; Braithwaite, Murphy and Reinhart, 2007), our study suggests this might not be an appropriate way of viewing these concepts. In the same way that Worden and Mclean $(2014,2018)$ have recently found that the effects of procedural justice and procedural injustice differ, our understanding of what leads to compliance and defiance may also differ. These findings highlight the utility of Braithwaite's (2009) motivational postures to operationalise, and distinguish between, 
compliance and defiance in policing studies. In other words, just as considerable attention has been focused on the operationalisation of police legitimacy (e.g. Tankebe, 2013) and procedural justice (e.g. Goodman-Delahunty, 2010), more attention should be devoted to the measurement of compliance and defiance, or at least the dispositions to defy or comply with authorities such as the police.

\section{Conclusion}

We conclude our paper by drawing attention back to the relationship between police and ethnic minority communities. Research finds that ethnic minority group members are typically less trusting of the police (Tyler, 2005), perceive more bias in their treatment by the police (Murphy and Cherney, 2012; Weitzer and Tuch, 1999), evaluate police behaviour more negatively (Tyler, 2001), and report more defiant and less compliant attitudes towards police compared to majority group members (Murphy and Cherney, 2012; Weitzer and Brunson, 2009). Our study suggests that increasing the amount of procedural justice police use should be effective in promoting commitment and capitulation, as well reducing resistance (and to some extent disengagement). At the same time, and rather than applying a blanket approach where by procedural justice is considered a panacea for all ills, it remains important that police work closely with cultural representatives and community leaders to avoid ethnic minority group disengagement. 


\section{References}

ABS. 2006, 2011, 2013. Census community profiles by location. Available from: http://www.censusdata.abs.gov.au/.

Blader, S. L., and Tyler, T. R. 2009. Testing and extending the group engagement model: Linkages between social identity, procedural justice, economic outcomes, and extrarole behavior. Journal of applied psychology, 94 (2), 445.

Bogardus, E. S. 1928. Immigration and race attitudes, Boston: L D.C. Heath and Co.

Bozeman, W. P., Stopyra, J. P., Klinger, D. A., Martin, B. P., Graham, D. D., Johnson III, J. C., Mahoney-Tesoriero, K. and Vail, S. J. 2018. Injuries associated with police use of force. Journal of trauma and acute care surgery, 84 (3), 466-472.

Bradford, B. 2014. Policing and social identity: Procedural justice, inclusion and cooperation between police and public. Policing and society, 24 (1), 22-43.

Bradford, B., Murphy, K., and Jackson, J. 2014. Officers as mirrors: Policing, procedural justice and the (re) production of social identity. British journal of criminology, 54(4), 527-550.

Braithwaite, V. 2003. Dancing with tax authorities: Motivational postures and noncompliant actions, In V. Braithwaite (Ed.), Taxing Democracy: Understanding Tax Avoidance and Evasion, Aldershot: Ashgate, 271-290.

Braithwaite, V. A. 2009. Defiance in taxation and governance: Resisting and dismissing authority in a democracy. Edward Elgar Publishing.

Braithwaite, V., Murphy, K., and Reinhart, M. 2007. Taxation threat, motivational postures, and responsive regulation. Law and policy, 29 (1), 137-158.

Brown, B., and Benedict, W. R. 2002. Perceptions of the police: Past findings, methodological issues, conceptual issues and policy implications. Policing: an international journal of police strategies and management, 25 (3), 543-580. 
Cao, L., Frank, J., and Cullen, F. T. 1996. Race, community context and confidence in the police. American journal of police, 15(1), 3-22.

Challice, G. and Johnson, H. 2005. The Australian component of the 2004 International Crime Victimisation Survey. Technical and background paper (Vol. 16). Canberra: Australian Institute of Criminology.

Cherney, A., and Murphy, K. 2011. Understanding the Contingency of Procedural Justice Outcomes. Policing: A journal of policy and practice, 5 (3), 228-235.

Clay-Warner, J. 2001. Perceiving procedural injustice: The effects of group membership and status. Social psychology quarterly, 64 (3), 224-238.

De Cremer, D., and Sedikides, C. 2005. Self-uncertainty and responsiveness to procedural justice. Journal of experimental social psychology, 41 (2), 157-173.

Deutsch, M., and Steil, J. M. (1988). Awakening the sense of injustice. Social justice research, 2 (1), 3-23.

Dixon, D., and Maher, L. 2002. Anh Hai: Policing, culture and social exclusion in a street heroin market. Policing and society, 12 (2), 93-110.

Donner, C., Maskaly, J., Fridell, L., and Jennings, W. G. 2015. Policing and procedural justice: a state-of-the-art review. Policing: an international journal of police strategies and management, 38 (1), 153-172.

Dunn K., Pelleri D. and Maeder-Han, K. 2011 Attacks on Indian students: The commerce of denial in Australia. Race and Class 52(4), 71-88.

Engel, R. S. 2003. Explaining suspects' resistance and disrespect toward police. Journal of criminal justice, 31 (5), 475-492.

Factor, R., Mahalel, D., Rafaeli, A., and Williams, D. R. 2013. A social resistance perspective for delinquent behaviour among non-dominant minority groups. British Journal of Criminology, 53(5), 784-804. 
Goodman-Delahunty, J. 2010. Four ingredients: New recipes for procedural justice in Australian policing. Policing: A journal of policy and practice, 4 (4), 403-410.

Griffiths, C. E. 2018. The disjuncture between confidence and cooperation: Police contact amongst Polish migrants and established residents. European journal of criminology, 15(2), 197-216.

Hartner, M., Rechberger, S., Kirchler, E., and Schabmann, A. 2008. Procedural fairness and tax compliance. Economic analysis and policy, 38, 137-152.

Huo, Y. J. (2003). Procedural justice and social regulation across group boundaries: Does subgroup identity undermine relationship-based governance? Personality and Social Psychology bulletin, 29(3), 336-348.

Huo, Y. J., Smith, H. J., Tyler, T. R., and Lind, E. A. 1996. Superordinate identification, subgroup identification, and justice concerns: Is separatism the problem, is assimilation the answer? Psychological science, 7(1), 40-45.

Jackson, J., Bradford, B., Stanko, B., and Hohl, K. 2013. Just authority?: Trust in the police in England and Wales. Oxon, UK: Routledge.

Lai, Y. L., and Zhao, J. S. 2010. The impact of race/ethnicity, neighborhood context, and police/citizen interaction on residents' attitudes toward the police. Journal of criminal justice, 38(4), 685-692.

MacDonald, J. M., Kaminski, R. J., and Smith, M. R. 2009. The effect of less-lethal weapons on injuries in police use-of-force events. American journal of public health, 99 (12), 2268-2274.

Madon, N. S., Murphy, K., and Sargeant, E. 2017. Promoting police legitimacy among disengaged minority groups: Does procedural justice matter more? Criminology and criminal justice, 17 (5), 624-642. 
Mason, G. 2012. 'I am tomorrow': Violence against Indian students in Australia and political denial. Australian and New Zealand journal of criminology, 45 (1), 425.

Mastrofski, S. D., Snipes, J. B., and Supina, A. E. 1996. Compliance on demand: The public's response to specific police requests. Journal of research in crime and delinquency, 33 (3), 269-305.

Mazerolle, L., Wickes, R., Cherney, A., Murphy, K., Sargeant, E. and Zahnow, R. 2012 Community variations in crime: A spatial and ecometric analysis wave 3. ARC Centre of Excellence in Policing and Security: Brisbane.

Meredyth, D., McKernan, H., and Evans, R. 2010. Police and Vietnamese-Australian communities in multi-ethnic Melbourne. Policing: A journal of policy and practice, 4 (3), 233-240.

Murphy, K. 2013. Policing at the margins: Fostering trust and cooperation among ethnic minority groups. Journal of policing, intelligence and counter terrorism, 8(2), 184-199.

Murphy, K. 2016. Turning defiance into compliance with procedural justice: understanding reactions to regulatory encounters through motivational posturing. Regulation and governance, 10 (1), 93-109.

Murphy, K., and Cherney, A. 2011. Fostering cooperation with the police: How do ethnic minorities in Australia respond to procedural justice-based policing?. Australian and New Zealand journal of criminology, 44 (2), 235-257.

Murphy, K., and Cherney, A. 2012. Understanding cooperation with police in a diverse society. British journal of criminology, 52(1), 181-201.

Murphy, K., Cherney, A., Wickes, R., Mazerolle, L., and Sargeant, E. 2012. The community capacity survey-face-to-face ethnic minority interviews: 
Methodology and preliminary findings. ARC Centre for excellence in policing and security: Brisbane.

Murphy, K., Cramer, R. J., Waymire, K. A., and Barkworth, J. 2018. Police bias, social identity, and minority groups: A social psychological understanding of cooperation with police. Justice quarterly, 35(6), 1105-1130.

Murphy, K., Hinds, L., and Fleming, J. 2008. Encouraging public cooperation and support for police. Policing and society 18 (2), 136-55.

Murphy, K., Murphy, B., and Mearns, M. 2010. 'The 2009 Crime, Safety and Policing in Australia Survey': Survey Methodology and Preliminary Findings. Alfred Deakin Research Institute, Deakin University.

Murphy, K., Sargeant, E., and Cherney, A. 2015. The importance of procedural justice and police performance in shaping intentions to cooperate with the police: Does social identity matter?. European journal of criminology, 12 (6), 719-738.

Murphy, K., Tyler, T. R., and Curtis, A. 2009. Nurturing regulatory compliance: Is procedural justice effective when people question the legitimacy of the law? Regulation and governance, 3 (1), 1-26.

Oliveira, A., and Murphy, K. 2015. Race, social identity, and perceptions of police bias. Race and justice, 5 (3), 259-277.

Poynting, S. and Noble, G. 2004. Living with racism: The experience and reporting by Arab and Muslim Australians of discrimination, abuse and violence since 11 September 2001. Report to the Human Rights and Equal Opportunity Commission. Sydney, Australia: Human Rights and Equal Opportunities Commission.

Poynting, S., Noble, G., Tabar, P., and Collins, J. 2004. Bin Laden in the suburbs: Criminalising the Arab other. Sydney, Australia: Institute of Criminology. 
Reisig, M. D., and Parks, R. B. 2000. Experience, quality of life, and neighborhood context: A hierarchical analysis of satisfaction with police. Justice quarterly, 17(3), 607-630.

Reith, C. 1975. The blind eye of history: A study of the origins of the present police era. Montclair, N. J.: Patterson Smith.

Sargeant, E., Murphy, K., and Cherney, A. 2014. Ethnicity, trust and cooperation with police: Testing the dominance of the process-based model. European journal of criminology, 11 (4), 500-524.

Sivasubramaniam, D., and Goodman-Delahunty, J. 2008. Ethnicity and trust: perceptions of police bias. International journal of police science and management, 10(4), 388-401.

Skogan, W. G. 2006. Asymmetry in the impact of encounters with police. Policing and society, 16 (02), 99-126.

Smith, H. J., Tyler, T. R., Huo, Y. J., Ortiz, D. J., and Lind, E. A. 1998. The selfrelevant implications of the group-value model: Group membership, self-worth, and treatment quality. Journal of experimental social psychology, 34 (5), 470493.

Sunshine, J. and Tyler, T. R. 2003. The role of procedural justice and legitimacy in shaping public support for policing. Law and society review, 37 (3), 513-548.

Tajfel, H. 1972. Social categorization (English translation of "La catagorisation sociale"). In S. Moscovici (Ed.), Intro- duction a la psychologie sociale, vol. 1: 272-302. Paris: Larousse

Tankebe, J. 2009. Public cooperation with the police in Ghana: Does procedural fairness matter? Criminology, 47 (4), 1265-1293. 
Tankebe, J. 2013. Viewing things differently: The dimensions of public perceptions of police legitimacy. Criminology, 51 (1), 103-135.

Tyler, T. R. 2001. Public trust and confidence in legal authorities: What do majority and minority group members want from the law and legal institutions?. Behavioral sciences and the law, 19 (2), 215-235.

Tyler, T. R. 2005. Policing in black and white: Ethnic group differences in trust and confidence in the police. Police quarterly, 8 (3), 322-342.

Tyler, T. R., and Blader, S. L. 2000. Cooperation in groups: Procedural justice, social identity, and behavioral engagement, Psychology Press: Philadelphia, PA..

Tyler, T. R., and Blader, S. L. 2003. The group engagement model: Procedural justice, social identity, and cooperative behavior. Personality and social psychology review, 7 (4), 349-361.

Tyler, T. R., Boeckmann, R. J., Smith, H. J., and Huo, Y. J. 1997. Social justice in a diverse society. Boulder: Westview Press.

Tyler, T., Degoey, P., and Smith, H. 1996. Understanding why the justice of group procedures matters: A test of the psychological dynamics of the group-value model. Journal of personality and social psychology, 70 (5), 913.

Tyler, T. R., and Fagan, J. 2008. Legitimacy and cooperation: Why do people help the police fight crime in their communities? Ohio State Journal of Criminal Law, 6, 231-276

Tyler, T. R., and Lind, E. A. 1992. A relational model of authority in groups. In Advances in experimental social psychology (Vol. 25, pp. 115-191). Academic Press.

Viki, G. T., Culmer, M. J., Eller, A., and Abrams, D. 2006. Race and willingness to cooperate with the police: The roles of quality of contact, attitudes towards the 
behaviour and subjective norms. British journal of social psychology, 45(2), 285-302.

Weitzer, R., and Brunson, R. K. 2009 Strategic responses to the police among inner-city youth. The sociological quarterly, 50 (2), 235-256.

Weitzer, R., and Tuch, S. A. 1999. Race, class, and perceptions of discrimination by the police. Crime and delinquency, 45 (4), 494-507.

White, R. (2009). Ethnic diversity and differential policing in Australia: The good, the bad and the ugly. Journal of international migration and integration, 10 (4), $359-375$.

Wolfe, S. E., Nix, J., Kaminski, R., and Rojek, J. 2016. Is the effect of procedural justice on police legitimacy invariant? Testing the generality of procedural justice and competing antecedents of legitimacy. Journal of quantitative criminology, 32 (2), 253-282.

Worden R.E., and McLean S.J. 2014. Assessing police performance in citizen encounters: police legitimacy and management accountability. Report to the National Institute of Justice. Albany, NY: John F. Finn Institute for Public Safety, Inc

Worden, R. E., and McLean, S. J. 2018. Measuring, managing, and enhancing procedural justice in policing, promise and pitfalls. Criminal justice policy review, 29 (2), 149-171. 
Table 1. Descriptive Statistics

\begin{tabular}{|l|r|r|r|r|}
\hline & \multicolumn{1}{|c|}{ Min } & \multicolumn{1}{c|}{ Max } & Mean/\% & \multicolumn{1}{c|}{ SD } \\
\hline Age & 18 & 86 & 39.17 & 12.861 \\
\hline Male & .00 & 1.00 & $50.10 \%$ & .500 \\
\hline Tertiary educated & .00 & 1.00 & $66.22 \%$ & .473 \\
\hline Vietnamese & .00 & 1.00 & $34.19 \%$ & .475 \\
\hline Indian & .00 & 1.00 & $32.91 \%$ & .470 \\
\hline Arabic-speaking & .00 & 1.00 & $32.91 \%$ & .470 \\
\hline Phase 2 & .00 & 1.00 & $38.65 \%$ & .487 \\
\hline Low income & .00 & 1.00 & $30.74 \%$ & .462 \\
\hline Full time employed & .00 & 1.00 & $50.88 \%$ & .500 \\
\hline Prior contact with & .00 & 1.00 & $29.39 \%$ & .456 \\
police & 1.00 & 5.00 & 3.70 & .630 \\
\hline Procedural justice & 1.00 & 5.00 & 4.10 & .620 \\
\hline Superordinate identity & 1.33 & 5.00 & 4.19 & .536 \\
\hline Commitment & 1.00 & 5.00 & 3.76 & .663 \\
\hline Capitulation & 1.00 & 5.00 & 3.34 & .756 \\
\hline Resistance & 1.00 & 5.00 & 2.36 & .828 \\
\hline Disengagement & & & & \\
\hline
\end{tabular}


Table 2. Principal components factor analysis with varimax rotation

\begin{tabular}{|c|c|c|c|c|c|c|}
\hline & \multicolumn{6}{|c|}{ Factor } \\
\hline & 1 & 2 & 3 & 4 & 5 & 6 \\
\hline \multicolumn{7}{|l|}{ Commitment } \\
\hline I obey the law with good will. & & & .810 & & & \\
\hline Obeying the police is the right thing to do. & & & .851 & & & \\
\hline I feel a strong commitment to help police. & & & .646 & & & \\
\hline \multicolumn{7}{|l|}{ Capitulation } \\
\hline $\begin{array}{l}\text { No matter how fair or unfair the police are, the best option is to always cooperate with } \\
\text { them. }\end{array}$ & & & & & .741 & \\
\hline If you cooperate with police, they are likely to be cooperative with you. & & & & & .658 & \\
\hline $\begin{array}{l}\text { Even if the police find out you are doing something wrong they will respect you as } \\
\text { long as you admit your mistake. }\end{array}$ & & & & & .719 & \\
\hline \multicolumn{7}{|l|}{ Resistance } \\
\hline $\begin{array}{l}\text { Police are more interested in catching you doing the wrong thing than helping you to } \\
\text { do the right thing. }\end{array}$ & & & & .741 & & \\
\hline If you don't cooperate with police, they will get tough with you. & & & & .695 & & \\
\hline Once police think you are a trouble maker, they will never change their mind. & & & & .781 & & \\
\hline \multicolumn{7}{|l|}{ Disengagement } \\
\hline I do not care if I am not doing the right thing by police. & & & & & & .838 \\
\hline $\begin{array}{l}\text { I don't think there is much the police can do to me to make me obey the law if I don't } \\
\text { want to. }\end{array}$ & & & & & & .846 \\
\hline \multicolumn{7}{|l|}{ Procedural justice } \\
\hline Police try to be fair when making decisions. & .759 & & & & & \\
\hline Police treat people fairly. & .790 & & & & & \\
\hline Police treat people with dignity and respect. & .749 & & & & & \\
\hline Police are always polite when dealing with people. & .678 & & & & & \\
\hline Police listen to people before making decisions. & .739 & & & & & \\
\hline
\end{tabular}




\begin{tabular}{|c|c|c|c|c|c|c|}
\hline & \multicolumn{6}{|c|}{ Factor } \\
\hline & 1 & 2 & 3 & 4 & 5 & 6 \\
\hline Police make decisions based upon facts, not their personal biases or opinions. & .766 & & & & & \\
\hline Police respect people's rights when decisions are made. & .770 & & & & & \\
\hline \multicolumn{7}{|l|}{ Superordinate identity } \\
\hline I see myself first and mainly as a member of the Australian community. & & .818 & & & & \\
\hline $\begin{array}{l}\text { It is important for me to be seen by others to be a member of the Australian } \\
\text { community. }\end{array}$ & & .853 & & & & \\
\hline I am proud to be an Australian. & & .770 & & & & \\
\hline What Australia stands for is important to me. & & .553 & & & & \\
\hline Eigenvalue & 5.713 & 2.388 & 1.825 & 1.680 & 1.275 & 1.109 \\
\hline$\%$ variance explained & 25.969 & 10.853 & 8.298 & 7.639 & 5.795 & 5.039 \\
\hline
\end{tabular}

Note: Extraction method: Principle components analysis with varimax rotation. Only factor loadings $>0.40$ are displayed. 
Table 3. Regression Analyses Predicting Commitment ( $\mathrm{N}=1,382)$

\begin{tabular}{|c|c|c|c|c|c|c|c|c|c|c|c|c|}
\hline \multirow[b]{2}{*}{ COMMITMENT } & \multicolumn{3}{|c|}{ Model 1} & \multicolumn{3}{|c|}{ Model 2} & \multicolumn{3}{|c|}{ Model 3} & \multicolumn{3}{|c|}{ Model 4} \\
\hline & B(SE) & $\mathbf{B}$ & & B(SE) & $\boldsymbol{\beta}$ & & B(SE) & $\beta$ & & B(SE) & $\boldsymbol{\beta}$ & \\
\hline Age & $.003(.001)$ & .083 & $* *$ & $.003(.001)$ & .076 & $* *$ & $.002(.001)$ & .052 & $*$ & $.002(.001)$ & .053 & $*$ \\
\hline Male & $-.017(.029)$ & -.016 & & $-.014(.027)$ & -.014 & & $-.021(.026)$ & -.020 & & $-.020(.026)$ & -.019 & \\
\hline Tertiary Education & $.016(.033)$ & .014 & & $.034(.030)$ & .031 & & $.028(.030)$ & .025 & & $.026(.030)$ & .023 & \\
\hline \multicolumn{13}{|l|}{$\begin{array}{l}\text { Ethnicity } \\
\text { (ref Vietnamese) }\end{array}$} \\
\hline Indian & $.168(.037)$ & .151 & $* * *$ & $.120(.034)$ & .108 & $* * *$ & $.128(.034)$ & .115 & $* * *$ & $.131(.034)$ & .118 & $* * *$ \\
\hline Arabic-speaking & $.191(.035)$ & .172 & $* * *$ & $.196(.032)$ & .176 & $* * *$ & $.161(.032)$ & .145 & $* * *$ & $.169(.032)$ & .151 & $* * *$ \\
\hline Wave 2 & $.053(.028)$ & .050 & & $.024(.026)$ & .023 & & $.018(.026)$ & .017 & & $.021(.026)$ & .020 & \\
\hline Low Income & $-.024(.032)$ & -.022 & & $-.006(.030)$ & -.005 & & $-.004(.029)$ & -.004 & & $-.001(.029)$ & .000 & \\
\hline Employed Fulltime & $-.047(.032)$ & -.045 & & $-.028(.030)$ & -.027 & & $-.038(.029)$ & -.037 & & $-.038(.029)$ & -.037 & \\
\hline Police Contact & $-.057(.031)$ & -.050 & & $-.039(.029)$ & -.034 & & $-.028(.028)$ & -.024 & & $-.026(.028)$ & -.022 & \\
\hline Procedural Justice & & & & $.319(.020)$ & .387 & $* * *$ & $.288(.020)$ & .349 & $* * *$ & $.292(.020)$ & .354 & $* * *$ \\
\hline Superordinate Identity & & & & & & & $.160(.021)$ & .190 & $* * *$ & $.155(.021)$ & .184 & $* * *$ \\
\hline $\begin{array}{l}\text { Procedural JusticeX } \\
\text { Superordinate Identity }\end{array}$ & & & & & & & & & & $-.054(.028)$ & -.047 & \\
\hline Intercept & $3.977(.065)$ & & $* * *$ & $3.977(.060)$ & & $* * *$ & $4.035(.059)$ & & $* * *$ & $4.033(.059)$ & & $* * *$ \\
\hline $\bar{R}^{2}$ & \multicolumn{3}{|c|}{.030} & \multicolumn{3}{|c|}{.177} & \multicolumn{3}{|c|}{.209} & \multicolumn{3}{|c|}{.211} \\
\hline$\Delta R^{2}$ & \multicolumn{3}{|c|}{$.036 * * *$} & \multicolumn{3}{|c|}{$.146 * * *$} & \multicolumn{3}{|c|}{$.033 * * *$} & \multicolumn{3}{|c|}{.002} \\
\hline
\end{tabular}

Note: ${ }^{*} \mathrm{p}<.05 ; * * \mathrm{p}<.01 ;{ }^{* * *} \mathrm{p}<.001$ 
Table 4. Regression Analyses Predicting Capitulation $(\mathrm{N}=1,375)$

\begin{tabular}{|c|c|c|c|c|c|c|c|c|c|c|c|c|}
\hline \multirow[b]{2}{*}{ CAPITULATION } & \multicolumn{3}{|c|}{ Model 1} & \multicolumn{3}{|c|}{ Model 2} & \multicolumn{3}{|c|}{ Model 3} & \multicolumn{3}{|c|}{ Model 4} \\
\hline & B(SE) & $\boldsymbol{\beta}$ & & B(SE) & $\boldsymbol{\beta}$ & & B(SE) & $\boldsymbol{\beta}$ & & B(SE) & $\boldsymbol{\beta}$ & \\
\hline Age & $.004(.001)$ & .082 & $* *$ & $.004(.001)$ & .076 & $* *$ & $.003(.001)$ & .059 & $*$ & $.003(.001)$ & .059 & $*$ \\
\hline Male & $.038(.037)$ & .029 & & $.039(.033)$ & .030 & & $.034(.033)$ & .026 & & $.035(.033)$ & .026 & \\
\hline Tertiary Educated & $-.087(.042)$ & -.062 & $*$ & $-.056(.038)$ & -.040 & & $-.059(.037)$ & -.042 & & $-.059(.037)$ & -.042 & \\
\hline \multicolumn{13}{|l|}{$\begin{array}{l}\text { Ethnicity (ref } \\
\text { Vietnamese) }\end{array}$} \\
\hline Indian & $.038(.047)$ & .027 & & $-.034(.042)$ & -.024 & & $-.029(.042)$ & -.021 & & $-.029(.042)$ & -.020 & \\
\hline Arabic-speaking & $.236(.044)$ & .167 & $* * *$ & $.237(.040)$ & .168 & $* * *$ & $.203(.040)$ & .144 & $* * *$ & $.204(.040)$ & .145 & $* * *$ \\
\hline Wave2 & $.087(.036)$ & .065 & $*$ & $.046(.032)$ & .034 & & $.039(.032)$ & .029 & & $.040(.032)$ & .030 & \\
\hline Low Income & $-.051(.041)$ & -.036 & & $-.033(.036)$ & -.023 & & $-.034(.036)$ & -.024 & & $-.034(.036)$ & -.024 & \\
\hline Fulltime Employed & $-.044(.041)$ & -.034 & & $-.018(.037)$ & -.014 & & $-.028(.036)$ & -.022 & & $-.028(.036)$ & -.021 & \\
\hline Police Contact & $.008(.039)$ & .005 & & $.024(.035)$ & .016 & & $.028(.035)$ & .019 & & $.028(.035)$ & .019 & \\
\hline Procedural Justice & & & & $.461(.025)$ & .436 & $* * *$ & $.438(.026)$ & .414 & $* * *$ & $.439(.026)$ & .415 & $* * *$ \\
\hline Superordinate Identity & & & & & & & $.138(.027)$ & .125 & $* * *$ & $.138(.027)$ & .125 & $* * *$ \\
\hline $\begin{array}{l}\text { Procedural JusticeX } \\
\text { Superordinate Identity }\end{array}$ & & & & & & & & & & $-.012(.041)$ & -.007 & \\
\hline Intercept & $3.568(.082)$ & & $* * *$ & $3.569(.074)$ & & $* * *$ & $3.620(.074)$ & & $* * *$ & $3.619(.074)$ & & $* * *$ \\
\hline $\bar{R}^{2}$ & \multicolumn{3}{|c|}{.037} & \multicolumn{3}{|c|}{.224} & \multicolumn{3}{|c|}{.238} & \multicolumn{3}{|c|}{.237} \\
\hline$\Delta R^{2}$ & \multicolumn{3}{|c|}{$.044 * * *$} & \multicolumn{3}{|c|}{$.186 * * *$} & \multicolumn{3}{|c|}{$.014 * * *$} & \multicolumn{3}{|c|}{.000} \\
\hline
\end{tabular}

Note: ${ }^{*} \mathrm{p}<.05 ; * * \mathrm{p}<.01 ; * * * \mathrm{p}<.001$. 
Table 5. Regression Analyses Predicting Resistance $(\mathrm{N}=1,378)$

\begin{tabular}{|c|c|c|c|c|c|c|c|c|c|c|c|c|}
\hline \multirow[b]{2}{*}{ RESISTANCE } & \multicolumn{3}{|c|}{ Model 1} & \multicolumn{3}{|c|}{ Model 2} & \multicolumn{3}{|c|}{ Model 3} & \multicolumn{3}{|c|}{ Model 4} \\
\hline & B(SE) & $\boldsymbol{\beta}$ & & B(SE) & $\beta$ & & B(SE) & $\beta$ & & B(SE) & $\beta$ & \\
\hline Age & $-.001(.002)$ & -.017 & & $-.001(.002)$ & -.013 & & $-.001(.002)$ & -.018 & & $-.001(.002)$ & -.018 & \\
\hline Male & $.096(.042)$ & .063 & $*$ & $.094(.040)$ & .062 & $*$ & $.092(.040)$ & .060 & $*$ & $.096(.040)$ & .064 & $*$ \\
\hline Tertiary Educated & $-.079(.048)$ & -.049 & & $-.097(.046)$ & -.060 & $*$ & $-.099(.046)$ & -.061 & $*$ & $-.105(.046)$ & -.065 & $*$ \\
\hline \multicolumn{13}{|l|}{$\begin{array}{l}\text { Ethnicity (ref } \\
\text { Vietnamese) }\end{array}$} \\
\hline Indian & $.246(.053)$ & .151 & $* * *$ & $.288(.052)$ & .177 & $* * *$ & $.291(.052)$ & .179 & $* * *$ & $.300(.052)$ & .185 & $* * *$ \\
\hline Arabic-speaking & $.347(.050)$ & .213 & $* * *$ & $.342(.049)$ & .210 & $* * *$ & $.330(.049)$ & .203 & $* * *$ & $.353(.049)$ & .217 & $* * *$ \\
\hline Wave2 & $-.145(.041)$ & -.093 & $* * *$ & $-.119(.040)$ & -.077 & $* *$ & $-.121(.040)$ & -.078 & $* *$ & $-.112(.040)$ & -.072 & $*$ \\
\hline Low Income & $.070(.046)$ & .043 & & $.054(.045)$ & .033 & & $.055(.045)$ & .034 & & $.066(.045)$ & .040 & \\
\hline Fulltime Employed & $.052(.047)$ & .034 & & $.037(.045)$ & .025 & & $.034(.045)$ & .022 & & $.035(.045)$ & .023 & \\
\hline Police Contact & $.160(.045)$ & .095 & $* * *$ & $.143(.043)$ & .085 & $* *$ & $.147(.044)$ & .087 & $* *$ & $.153(.043)$ & .091 & $* * *$ \\
\hline Procedural Justice & & & & $-.284(.031)$ & -.236 & $* * *$ & $-.294(.032)$ & -.244 & $* * *$ & $-.282(.032)$ & -.234 & $* * *$ \\
\hline Superordinate Identity & & & & & & & $.052(.033)$ & .043 & & $.038(.033)$ & .031 & \\
\hline $\begin{array}{l}\text { Procedural Justice X } \\
\text { Superordinate Identity }\end{array}$ & & & & & & & & & & $-.159(.043)$ & -.095 & $* * *$ \\
\hline Intercept & $3.143(.094)$ & & $* * *$ & $3.142(.091)$ & & $* * *$ & $3.161(.092)$ & & $* * *$ & $3.154(.091)$ & & $* * *$ \\
\hline $\bar{R}^{2}$ & \multicolumn{3}{|l|}{.061} & \multicolumn{3}{|l|}{.115} & \multicolumn{3}{|l|}{.116} & \multicolumn{3}{|l|}{.124} \\
\hline$\Delta R^{2}$ & \multicolumn{3}{|l|}{$.067 * * *$} & \multicolumn{3}{|l|}{$.054 * * *$} & \multicolumn{3}{|l|}{.002} & \multicolumn{3}{|l|}{$.009 * * *$} \\
\hline
\end{tabular}

Note: ${ }^{*} \mathrm{p}<.05 ;{ }^{* *} \mathrm{p}<.01 ; * * * \mathrm{p}<.001$. 
Table 6. Regression Analyses Predicting Disengagement (N=1,367)

\begin{tabular}{|c|c|c|c|c|c|c|c|c|c|c|c|c|}
\hline \multirow[b]{2}{*}{ DISENGAGEMENT } & \multicolumn{3}{|c|}{ Model 1} & \multicolumn{3}{|c|}{ Model 2} & \multicolumn{3}{|c|}{ Model 3} & \multicolumn{3}{|c|}{ Model 4} \\
\hline & B(SE) & $\beta$ & & B(SE) & $\boldsymbol{\beta}$ & & B(SE) & $\beta$ & & B(SE) & $\beta$ & \\
\hline Age & $-.004(.002)$ & -.058 & $*$ & $-.004(.002)$ & -.058 & $*$ & $-.004(.002)$ & -.063 & $*$ & $-.004(.002)$ & -.063 & $*$ \\
\hline Male & $.034(.047)$ & .020 & & $.034(.047)$ & .020 & & $.031(.047)$ & .019 & & $.026(.047)$ & .016 & \\
\hline Tertiary Educated & $-.083(.054)$ & -.047 & & $-.084(.054)$ & -.047 & & $-.086(.054)$ & -.049 & & $-.079(.054)$ & -.045 & \\
\hline \multicolumn{13}{|l|}{$\begin{array}{l}\text { Ethnicity (ref } \\
\text { Vietnamese) }\end{array}$} \\
\hline Indian & $.153(.060)$ & .086 & $* *$ & $.156(.061)$ & .087 & $*$ & $.159(.061)$ & .089 & $* *$ & $.149(.061)$ & .083 & $*$ \\
\hline Arabic-speaking & $.080(.057)$ & .045 & & $.080(.057)$ & .045 & & $.068(.058)$ & .038 & & $.043(.058)$ & .024 & \\
\hline Wave2 & $.021(.046)$ & .012 & & $.023(.046)$ & .013 & & $.021(.046)$ & .012 & & $.010(.046)$ & .006 & \\
\hline Low Income & $-.024(.052)$ & -.013 & & $-.025(.052)$ & -.014 & & $-.024(.052)$ & -.014 & & $-.036(.052)$ & -.020 & \\
\hline Fulltime Employed & $-.079(.053)$ & -.047 & & $-.080(.053)$ & -.048 & & $-.083(.053)$ & -.050 & & $-.084(.053)$ & -.050 & \\
\hline Police Contact & $-.051(.051)$ & -.028 & & $-.052(.051)$ & -.028 & & $-.049(.051)$ & -.026 & & $-.055(.051)$ & -.030 & \\
\hline Procedural Justice & & & & $-.016(.036)$ & -.012 & & $-.027(.037)$ & -.020 & & $-.040(.037)$ & -.031 & \\
\hline Superordinate Identity & & & & & & & $.053(.038)$ & .040 & & $.069(.038)$ & .051 & \\
\hline $\begin{array}{l}\text { Procedural JusticeX } \\
\text { Superordinate Identity }\end{array}$ & & & & & & & & & & $.176(.050)$ & .096 & $* *$ \\
\hline Intercept & $2.526(.106)$ & & & $2.526(.106)$ & & $* * *$ & $2.545(.107)$ & & $* * *$ & $2.551(.107)$ & & $* * *$ \\
\hline $\bar{R}^{2}$ & \multicolumn{3}{|l|}{.007} & \multicolumn{3}{|l|}{.007} & \multicolumn{3}{|l|}{.008} & \multicolumn{3}{|l|}{.016} \\
\hline$\Delta R^{2}$ & \multicolumn{3}{|l|}{$.014 *$} & \multicolumn{3}{|l|}{.000} & \multicolumn{3}{|l|}{.001} & \multicolumn{3}{|l|}{$.009 * *$} \\
\hline
\end{tabular}

Note: ${ }^{*} \mathrm{p}<.05 ; * * \mathrm{p}<.01 ; * * * \mathrm{p}<.001$. 


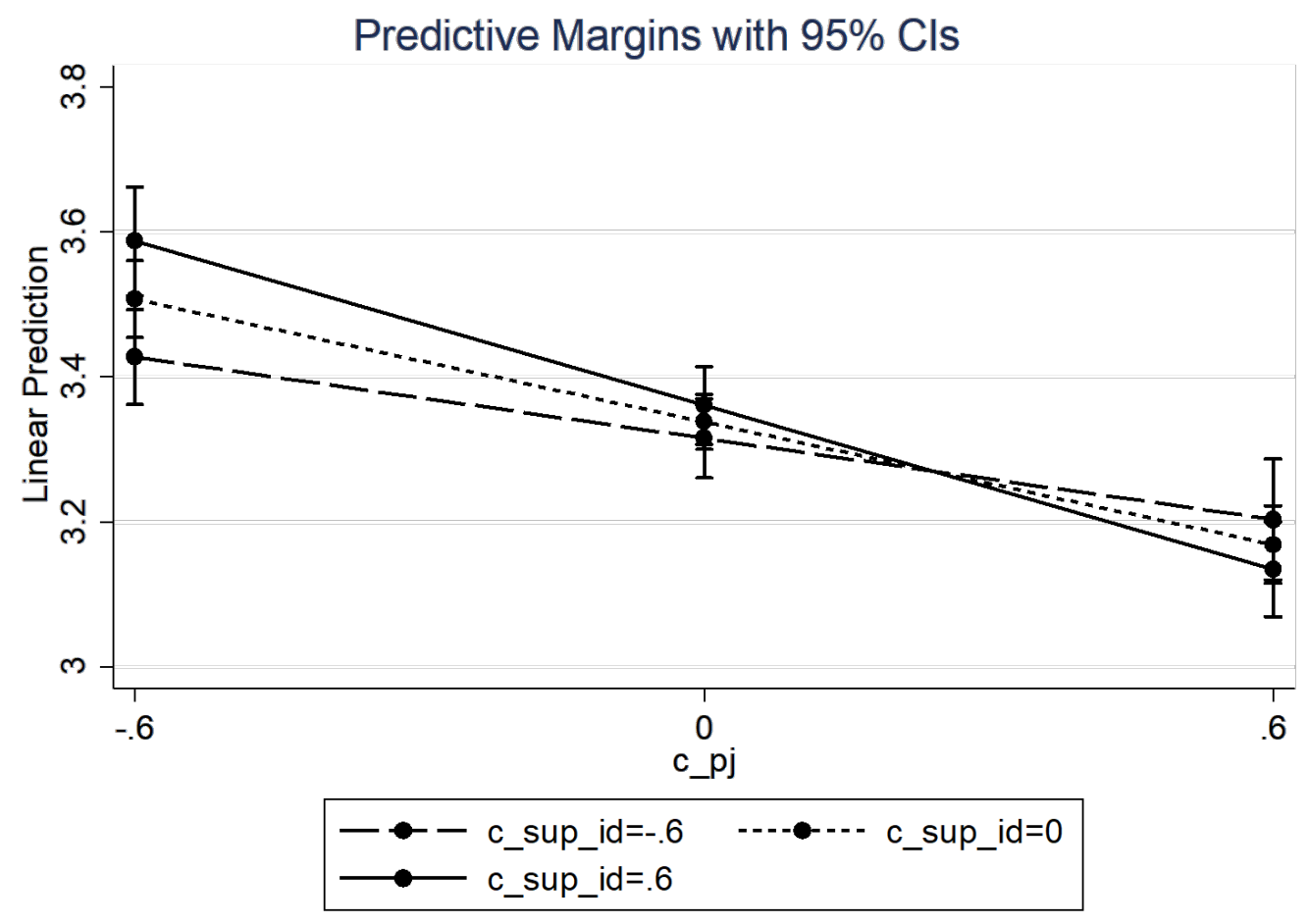

Figure 1 Plot of Interaction Term Predicting Resistance

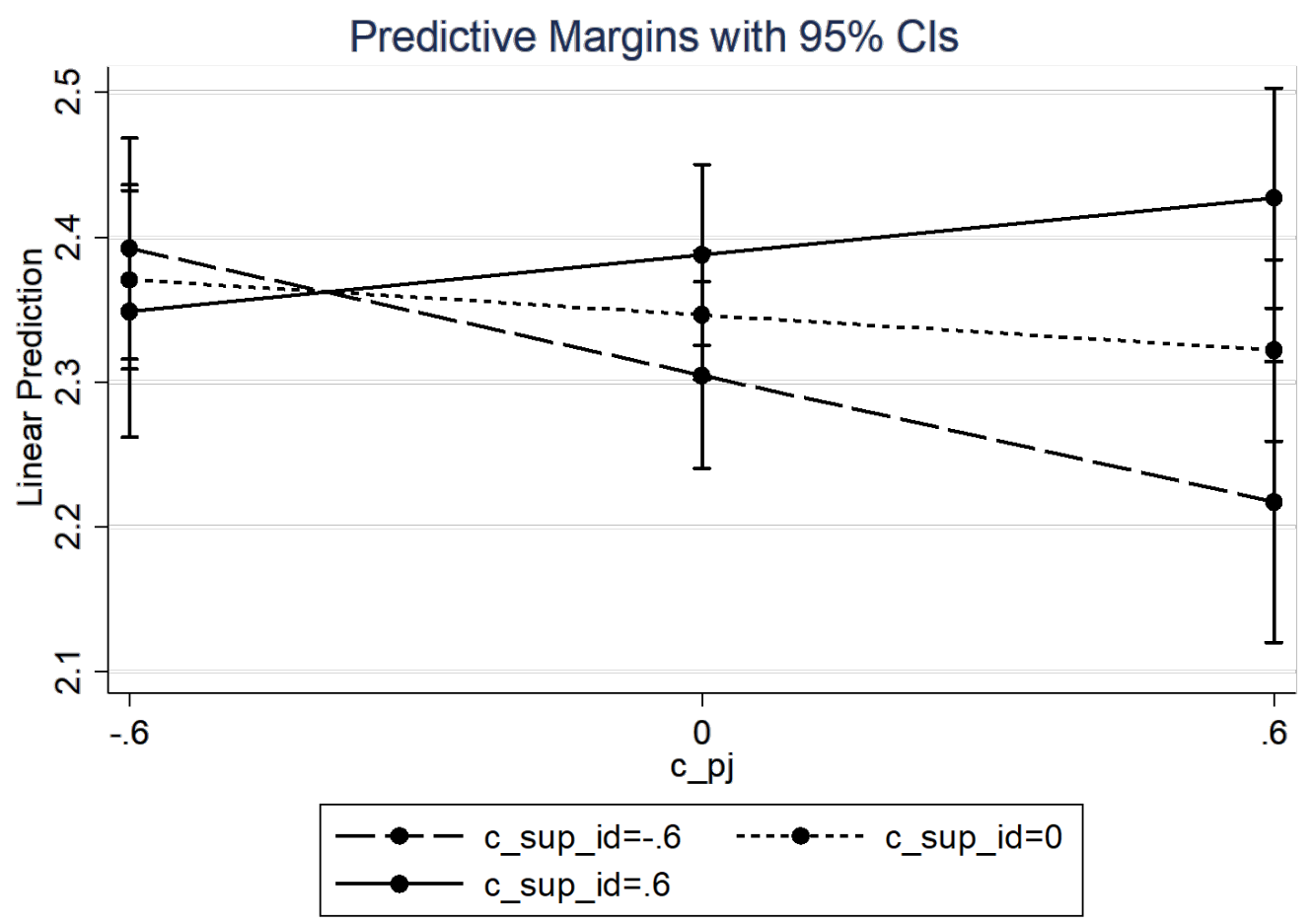

Figure 2 Plot of the Interaction Term Predicting Disengagement 
Table 7. Simple Slopes Analysis Resistance

\begin{tabular}{|l|l|l|l|}
\hline $\begin{array}{l}\text { Superordinate } \\
\text { Identity }\end{array}$ & $\mathrm{dy} / \mathrm{dx}$ & $\begin{array}{l}\text { Std. } \\
\text { Err. }\end{array}$ & \\
\hline-0.6 & -0.187 & 0.043 & $* * *$ \\
\hline 0 & -0.282 & 0.032 & $* * *$ \\
\hline 0.6 & 0.377 & 0.039 & $* * *$ \\
\hline
\end{tabular}

Table 8. Simple Slopes Analysis Disengagement

\begin{tabular}{|l|l|l|l|}
\hline $\begin{array}{l}\text { Superordinate } \\
\text { Identity }\end{array}$ & $\mathrm{dy} / \mathrm{dx}$ & $\begin{array}{l}\text { Std. } \\
\text { Err. }\end{array}$ & \\
\hline-0.6 & -0.145 & 0.050 & $* *$ \\
\hline 0 & -0.040 & 0.037 & \\
\hline 0.6 & 0.065 & 0.045 & \\
\hline
\end{tabular}


Appendix 1: Auxiliary model predicting superordinate identity (used for Sobel tests predicting commitment $N=1,382$ )

\begin{tabular}{|c|c|c|}
\hline & B(SE) & \\
\hline Age & $.006(.001)$ & $* * *$ \\
\hline Male & $.045(.033)$ & \\
\hline Tertiary Educated & $.043(.038)$ & \\
\hline \multicolumn{3}{|c|}{ Ethnicity (ref Vietnamese) } \\
\hline Indian & $-.052(.043)$ & \\
\hline Arabic-speaking & $.220(.040)$ & $* * *$ \\
\hline Wave2 & $.038(.033)$ & \\
\hline Low Income & $-.009(.037)$ & \\
\hline Fulltime Employed & $.065(.037)$ & \\
\hline Police Contact & $-.069(.036)$ & \\
\hline Procedural Justice & $.195(.026)$ & $* * *$ \\
\hline Intercept & $-.121(.044)$ & $* *$ \\
\hline $\bar{R}^{2}$ & .092 & \\
\hline (n) & $.085 * * *$ & \\
\hline
\end{tabular}

Note: $* \mathrm{p}<.05 ; * * \mathrm{p}<.01 ; * * * \mathrm{p}<.001$. 
Appendix 2: Model predicting capitulation including outliers $(\mathrm{N}=1,381)$

\begin{tabular}{|l|l|l|}
\hline & $\mathbf{B}(\mathbf{S E})$ & \\
\hline Age & $.003(.001)$ & $*$ \\
\hline Male & $.037(.033)$ & \\
\hline Tertiary Educated & $-.054(.037)$ & \\
\hline Ethnicity (ref Vietnamese) & & \\
\hline Indian & $-.029(.042)$ & \\
\hline Arabic-speaking & $.204(.040)$ & $* * *$ \\
\hline Wave2 & $.043(.032)$ & \\
\hline Low Income & $-.038(.036)$ & \\
\hline Fulltime Employed & $-.026(.036)$ & \\
\hline Police Contact & $.022(.035)$ & \\
\hline Procedural Justice & $.456(.026)$ & $* * *$ \\
\hline Superordinate Identity & $.152(.027)$ & $* * *$ \\
\hline Procedural Justice X Superordinate Identity & $-.088(.037)$ & $*$ \\
\hline Intercept & $3.737(.043)$ & $* * *$ \\
\hline \multicolumn{1}{|c|}{$\overline{\boldsymbol{R}}^{2}$} & .259 & \\
\hline $\boldsymbol{R}^{2}$ & $.252^{* * *}$ & \\
\hline
\end{tabular}

Note: ${ }^{*} \mathrm{p}<.05 ; * * \mathrm{p}<.01 ; * * * \mathrm{p}<.001$. 
Appendix 3: Auxiliary model predicting superordinate identity (used for Sobel tests predicting capitulation $\mathrm{N}=1,375$ )

\begin{tabular}{|c|c|c|}
\hline & B(SE) & \\
\hline Age & $.006(.001)$ & $* * *$ \\
\hline Male & $.035(.032)$ & \\
\hline Tertiary Educated & $.025(.037)$ & \\
\hline \multicolumn{3}{|c|}{ Ethnicity (ref Vietnamese) } \\
\hline Indian & $-.038(.042)$ & \\
\hline Arabic-speaking & $.247(.039)$ & $* * *$ \\
\hline Wave2 & $.048(.032)$ & \\
\hline Low Income & $.008(.036)$ & \\
\hline Fulltime Employed & $.074(.036)$ & $*$ \\
\hline Police Contact & $-.031(.035)$ & \\
\hline Procedural Justice & $.166(.025)$ & $* * *$ \\
\hline Intercept & $-.132(.042)$ & $* *$ \\
\hline $\bar{R}^{2}$ & .089 & \\
\hline (n) & $.082 * * *$ & \\
\hline
\end{tabular}

Note: $* \mathrm{p}<.05 ; * * \mathrm{p}<.01 ; * * * \mathrm{p}<.001$. 